\title{
Reflections on Mortality
}

\author{
Connie Nugent MLS
}

When Carnegie Mellon University professor Randy Pausch was diagnosed with a terminal illness in 2007, he had already agreed to participate in the university's "Journeys" series. For these lectures, professors were asked to consider their own mortality and to reflect on issues that mattered to them. As Dr. Pausch remarks in his book The Last Lecture, "I was energized by the idea of delivering a last lecture that really was a last lecture." During his preparation, he told his wife Jai, "I have a chance here to really think about what matters most to me, to cement how people will remember me, and to do whatever good I can on the way out."1

Reflecting on his mortality, he points out that many people have said "their illness gives them a new and deeper appreciation for life. Some even say they are grateful for their disease. I have no such gratitude for my cancer, although I'm certainly grateful for having advance notice of my death...In a sense, it allowed me to "leave the field under my own power."'1

His upbeat lecture and subsequent best-selling book concerned fulfilling childhood dreams and, more important, allowing others to fulfill their dreams. "So today's talk was about achieving childhood dreams," he summarized, "[but] it's not about how to achieve your dreams. It's about how to lead your life. If you lead your life the right way, the karma will take care of itself. The dreams will come to you."

In his book Mortality, Christopher Hitchens is not as sanguine about the chance to inspire others. His final illness attacks suddenly in a hotel room in New York, when "I came to consciousness feeling as if I were actually shackled to my own corpse." ${ }^{2}$ In one of those surreal moments, Hitchens likens his experience

Corresponding author: Connie Nugent

Contact Information: Connie.nugent1@gmail.com DOI: $10.12746 /$ swrccc.v7i28.547 of being tended by EMS personnel and transported to the hospital as "a very gentle and firm deportation, taking me from the country of the well across the stark frontier that marks off the land of malady... where the physicians at this sad border post had shown me a few other postcards from the interior"2 and advised him to see an oncologist.

Continuing the analogy, Hitchens remarks that "the new land is quite welcoming in its way"2 due to the professionalism and courtesy of its citizens; this new country-"Tumorville"-has a language and gestures of its own, as the patient learns new medical vocabulary and endures unsettling poking and prodding. Unlike Dr. Pausch, whose lecture and book are relentlessly upbeat and positive, Hitchens's reflections concentrate on the "imagery of struggle." He describes his voyage through Tumorville in unsparing detail; living in this new country is not fun. Losing the ability to speak, for example, is like "an amputation of part of the personality." Other than a cure, what Hitchens most wants back is the "freedom of speech." He devotes one section of his book on debunking the cliché "whatever doesn't kill me makes me stronger." At this point in his treatment, the pain in his arms, hands, and fingers threatens his ability to write-his pen and his voice were his raison d'être in Wellville. Hitchens's reflections on mortality are quite different from Dr. Pausch's. In fact, Hitchens considers Pausch's lecture and book to be "so sugary that you may need an insulin shot to withstand it."

Professor Randy Pausch and writer Christopher Hitchens each published reflections on their mortality after being struck with terminal illnesses. A century ago, American artist Winslow Homer (1836-1910) was felled by a stroke, complicated by chronic digestive trouble. In his last year of life, he reflected on his own mortality in his last oil painting Driftwood (1909). This seascape features a restless ocean whose waves begin in the upper left, gradually swell until they crash against the rocks in the center of the painting, then 


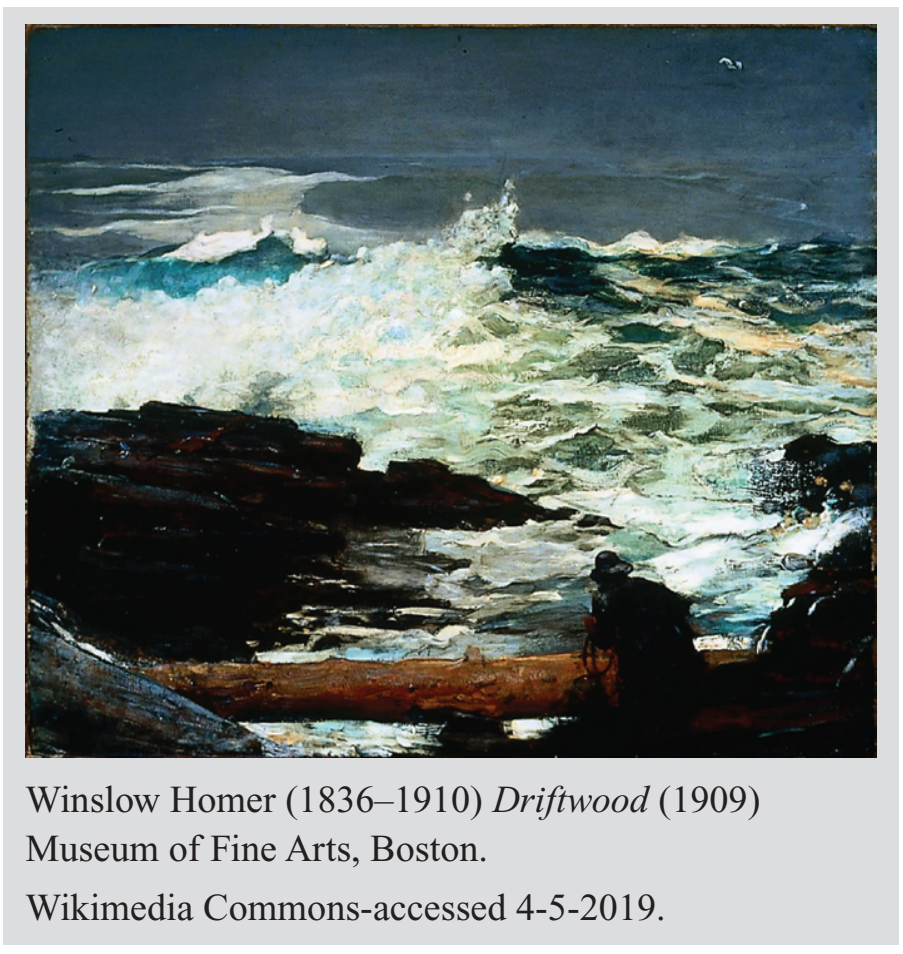

subside toward the lower right into gentle foam. In his analysis of Driftwood, art critic William Agee suggests that this watery transition reflects Shakespeare's Seven Ages of Man, from the swells of youthful potential to "that explosive burst, symbolic of a life filled with surging achievement" and ending in the reduced drips of spray of old age. ${ }^{3}$

Christopher Hitchens acknowledged his transition from Wellville to Tumorville as "whatever happens, this is the last day of my old life. No pretense of youth or youthfulness anymore. From now on an arduous awareness" of what he called "living dyingly."2 Winslow Homer places his avatar in the drips of spray in the lower right of Driftwood as a diminished shadowy figure attempting to move a dead tree. This waterlogged tree lies horizontally at the bottom of the painting, an effective symbol of death separating the man from the living sea. Many of Homer's paintings portray mortality, e.g., The Fox Hunt, but this painting represents his own "living dyingly." Regardless of his determination to move the tree, the man is doomed to fail. His rope is too short and the tree is too large. William Agee points out a further intimation of mortality, "the presence of the bird at the upper right, the old symbol of the Holy Spirit and the artist's soul."

Randy Pausch, Christopher Hitchens, and Winslow Homer shared the common experience of facing terminal illnesses. Each reflected on his mortality by producing a work of art that represents the range of human emotion from optimism, to bitterness, to resignation, to hope. Obviously, none wanted that final journey, but

\section{Because I could not stop for Death, He kindly stopped for me; \\ The carriage held but just ourselves And Immortality. ${ }^{4}$}

Keywords: Randy Pausch, Christopher Hitchens, Winslow Homer, mortality

Article citation: Nugent C. Reflections on Mortality. The Southwest Respiratory and Critical Care Chronicles 2019;7(28):55-56

From: Department of Internal Medicine, Texas Tech University Health Sciences Center, Lubbock, Texas

Submitted: 4/8/2019

Reviewer: Gilbert Berdine MD

Conflicts of interest: none

This work is licensed under a Creative Commons Attribution-ShareAlike 4.0 International License.

\section{REFERENCES}

1. Pausch, R, Zaslow J. The Last Lecture. New York: Hyperion, 2008.

2. Hitchens C. Mortality. New York: Twelve (Hachette Book Group), 2012.

3. Agee WC. "Intimations of Mortality." The Wall Street Journal. March 30-31, 2019.

4. Dickinson E. "Because I could not stop for Death." Oxford Book of American Verse. New York: Oxford University Press, 1950. 